\title{
THE EFFECTS OF ACTIVE IMMUNIZATION ON THE DECIDUAL CELL REACTION AND ECTOPIC BLASTOCYST DEVELOPMENT IN MICE
}

\author{
G. M. HETHERINGTON AND D. P. HUMBER \\ Clinical Research Centre, Watford Road, Harrow
}

(Received 4th October 1974)

One of the most striking features of early pregnancy in the mouse is the development of the decidual cell reaction (DCR). This cellular proliferation is induced in the uterine stroma by the presence of a blastocyst on the 4th day of pregnancy (the day of finding a vaginal plug was designated the 1st day of pregnancy). The significance of the DCR and the interactions between blastocyst and uterus, which result in its induction, are poorly understood.

Kirby, Billington \& James (1966) postulated that the DCR might be instrumental in preventing the rejection of the conceptus as foreign tissue. The extent of the DCR on the 7th day of pregnancy is dependent on the genotype of the mother and the genotype of the conceptus (Hetherington, 1971). Antigenic differences between mother and conceptus can apparently reduce the extent of the DCR. It is unlikely, however, that either the $\mathrm{H}-2$ or $\mathrm{H}-3$ locus is involved (Hetherington, 1973). The extent of the DCR can also be reduced by immunizing female mice to the antigens of the mating male (Clarke \& Hetherington, 1971).

In order to understand the mechanisms involved at the time of implantation which affect the development of the DCR, it is important to determine the genetic locus or loci involved. In the present study, CBA/CafTOf/Crc $(\mathrm{CBA} / \mathrm{Ca})$ and $\mathrm{C} 3 \mathrm{H} / \mathrm{He}$-mgfTOf/Crc $(\mathrm{C} 3 \mathrm{H} / \mathrm{He}-\mathrm{mg})$ mice maintained at the Clinical Research Centre and C57BL/10ScSnfNMRI/Lac (B10), B10.LpafLAGAf/Lac (B10.Lp-a) and B10.AfC3H/Hef/Lac (B10.A) mice maintained at the Laboratory Animal Centre, Carshalton, were used. Both the CBA and $\mathrm{C} 3 \mathrm{H}$ strains were derived from a cross between Bagg Albino and DBA (Strong, 1942). After a few generations of inbreeding, a series of lines was produced which included the CBA and $\mathrm{C} 3 \mathrm{H}$ strains. As a consequence, these strains are closely related and their $\mathrm{H}-2$ loci are identical. They differ, however, at the $H-3$ locus (for a comparison of the two genotypes, see Graff, 1970; Taylor, 1972). The effect of immunizing CBA mice to $\mathrm{C} 3 \mathrm{H}$ and vice versa on the development of the DCR after inter-strain matings and on the growth of inbred blastocysts transferred under the kidney capsule of mice of the opposite strain was studied. The congenic strains B10 $(H-2 b, H-3 a)$, B10.A $(H-2 a, H-3 a)$ and B10.Lp- $a(H-2 b, H-3 b)$ were used to investigate the effect of specific immunization to the antigens of the $\mathrm{H}-2$ and $\mathrm{H}-3$ loci on decidual development. 
Mice were immunized by four injections of spleen cells $\left(20\right.$ to $30 \times 10^{6}$ cells/injection) at 14-day intervals. Immunized mice were used 7 days after the final injection. Pregnant mice were killed on the 7 th day of pregnancy. Decidual tissue was dissected free from the uterus and weighed as described previously (Hetherington, 1971). Blastocysts were collected from the uterus on the 4th day of pregnancy and two blastocysts were transferred under the right kidney capsule of each host. Mice were killed 10 days after transfer and the extent of the haemorrhagic nodules was scored macroscopically.

Immunization of $\mathrm{C} 3 \mathrm{H}$ mice to CBA males significantly reduced the extent of the DCR after mating to CBA males $(P<0 \cdot 001$, Table 1$)$. Immunization of CBA mice to $\mathrm{C} 3 \mathrm{H}$ had no significant effect on the extent of the DGR induced after mating to $\mathrm{C} 3 \mathrm{H}$ males. Immunization to the antigens of either the $\mathrm{H}-2$ or $H-3$ locus had no significant effect on decidual development.

Table 1. Effect of immunization on decidual weight of mice on the 7th day of pregnancy after inter-strain matings

\begin{tabular}{|c|c|c|c|c|c|}
\hline $\begin{array}{l}\text { Strain of } \\
\text { dam }\end{array}$ & $\begin{array}{l}\text { Immune } \\
\text { status }\end{array}$ & $\begin{array}{l}\text { Strain of } \\
\text { sire }\end{array}$ & $\begin{array}{l}\text { No. of } \\
\text { mice }\end{array}$ & $\begin{array}{l}\text { Mean decidual } \\
\text { wt (mg) }\end{array}$ & $\begin{array}{l}\text { Significance } \\
\text { of difference }\end{array}$ \\
\hline CBA & $\begin{array}{l}\text { Unimmunized } \\
\text { control }\end{array}$ & G3H & 12 & $3 \cdot 38 \pm 0 \cdot 16$ & \multirow{2}{*}{ N.S. } \\
\hline CBA & $\begin{array}{l}\text { Immunized } \\
\text { to C3H }\end{array}$ & G3H & 10 & $3 \cdot 44 \pm 0 \cdot 14$ & \\
\hline G3H & $\begin{array}{l}\text { Unimmunized } \\
\text { control }\end{array}$ & CBA & 10 & $3 \cdot 56 \pm 0 \cdot 15$ & \multirow{2}{*}{$P<0.001$} \\
\hline G3H & $\begin{array}{l}\text { Immunized } \\
\text { to CBA }\end{array}$ & CBA & 13 & $2.75 \pm 0.08$ & \\
\hline B. 10 & $\begin{array}{l}\text { Unimmunized } \\
\text { control }\end{array}$ & B10 A & 24 & $4 \cdot 07 \pm 0.16$ & \multirow{2}{*}{ N.S. } \\
\hline B. 10 & $\begin{array}{l}\text { Immunized } \\
\text { to } \mathrm{B} 10 . \mathrm{A}\end{array}$ & B10.A & 24 & $4 \cdot 36 \pm 0 \cdot 15$ & \\
\hline B. 10 & $\begin{array}{l}\text { Unimmunized } \\
\text { control }\end{array}$ & B10.Lp- $a$ & 6 & $4 \cdot 36 \pm 0 \cdot 21$ & \multirow{2}{*}{ N.S. } \\
\hline B. 10 & $\begin{array}{l}\text { Immunized } \\
\text { to B10.Lp-a }\end{array}$ & B10.Lp- $a$ & 8 & $4 \cdot 68 \pm 0 \cdot 19$ & \\
\hline
\end{tabular}

Values are given as Mean \pm S.E.M. N.S., not significant.

Inbred blastocysts of the GBA strain transferred under the kidney capsule of $\mathrm{C} 3 \mathrm{H}$ mice immunized to $\mathrm{CBA}$ failed to produce any macroscopically visible haemorrhagic nodules, while $77.8 \%$ of control $\mathrm{C} 3 \mathrm{H}$ mice developed such nodules (Table 2). This suggests that trophoblast development was only inhibited in immunized $\mathrm{C} 3 \mathrm{H}$ mice. There was, however, no significant difference between immunized and control $\mathrm{CBA}$ mice receiving $\mathrm{C} 3 \mathrm{H}$ blastocysts.

The absence of any significant effect on decidual development in the experiments involving the congenic strains of mice indicates that neither the $H-2$ nor the $H-3$ locus is directly involved. Thus, although CBA and C3H mice differ at the $H-3$ locus, the effect on decidual development that was found when $\mathrm{C} 3 \mathrm{H}$ mice were immunized to $\mathrm{CBA}$ is unlikely to be due to this 
histocompatibility difference. This was further supported by the observation that the effect of immunization was not reciprocal.

The present study has shown that the extent of the DCR on the 7 th day of pregnancy and the development of ectopic blastocysts can be affected by the immunological status of the mother or host. This is in agreement with the work of Clarke \& Hetherington (1971) and Kirby et al. (1966). These studies involved strain combinations which differed at many loci, including the major histocompatibility locus, $H-2$. Here, $\mathrm{CBA}$ and $\mathrm{C} 3 \mathrm{H}$ mice were used which were genetically identical at the major histocompatibility locus and at many other specificities (Graff, 1970; Taylor, 1972), and congenic mice which differed only at the $H-2$ or $H-3$ locus. The results obtained concerning ectopic blastocyst development are in agreement with the recent work of Searle et al. (1974).

Table 2. Effect of immunization of $\mathrm{CBA}$ to $\mathrm{C} 3 \mathrm{H}$ strain and of $\mathrm{C} 3 \mathrm{H}$ to CBA strain on the ectopic development of blastocysts under the kidney capsule of mice

\begin{tabular}{|c|c|c|c|c|c|}
\hline $\begin{array}{c}\text { Genotype } \\
\text { of } \\
\text { blastocyst }\end{array}$ & $\begin{array}{l}\text { Strain } \\
\text { of } \\
\text { host }\end{array}$ & $\begin{array}{l}\text { Immune } \\
\text { status } \\
\text { of host }\end{array}$ & $\begin{array}{l}\text { No. } \\
\text { of } \\
\text { mice }\end{array}$ & $\begin{array}{l}\text { No. showing } \\
\text { haemorrhagic } \\
\text { nodules }\end{array}$ & $\begin{array}{c}\% \text { Showing } \\
\text { haemorrhagic } \\
\text { nodules }\end{array}$ \\
\hline $\begin{array}{l}\text { G3H } \\
\text { G3H } \\
\text { GBA } \\
\text { GBA }\end{array}$ & $\begin{array}{l}\text { CBA } \\
\text { CBA } \\
\text { C3H } \\
\text { C3H }\end{array}$ & $\begin{array}{l}\text { Gontrol } \\
\text { Immunized } \\
\text { Gontrol } \\
\text { Immunized }\end{array}$ & $\begin{array}{r}10 \\
12 \\
9 \\
11\end{array}$ & $\begin{array}{l}7 \\
9 \\
7 \\
0\end{array}$ & $\begin{array}{c}70 \cdot 0 \\
75 \cdot 0 \\
77 \cdot 8 \\
0\end{array}$ \\
\hline
\end{tabular}

The effect of immunization using the CBA and $\mathrm{C} 3 \mathrm{H}$ combination of mice demonstrates that the DCR and ectopic blastocysts can be affected by immunity to relatively minor transplantation antigens. Immunization of the CBA strain with $\mathrm{C} 3 \mathrm{H}$ spleen cells failed to have any significant effect on either the DCR or on ectopic blastocyst growth. Carter \& Wegmann (1973) described an antigen, probably associated with the $\mathrm{H}-2$ complex, which was designated $S p l-1$ and which resulted in unidirectional mixed lymphocyte cultures between $\mathrm{CBA}$ and $\mathrm{C} 3 \mathrm{H}$. They concluded that the one-way reaction was due to the presence of $S p l-1$ antigens on the surface of CBA spleen cells and the absence of this antigen on $\mathrm{C} 3 \mathrm{H}$ cells. It is possible, therefore, that the data presented here are due to the immunization of $\mathrm{C} 3 \mathrm{H}$ mice to the CBA spleen cell antigen $S p l-1$ and that the absence of a reciprocal effect is because of the inability to immunize CBA strain mice with $\mathrm{C} 3 \mathrm{H}$ spleen cells.

If the spleen cell antigen reported by Carter \& Wegmann (1973) is responsible for the unidirectional effect described here, then one must assume this antigen cross-reacts with, or is identical to, an antigen present in the early stages of embryonic development. Sensitization to this antigen results in the rejection of ectopically transplanted blastocysts and an impairment of the embryo's ability to induce decidual tissue.

It is interesting to speculate that much of the controversy regarding $\mathrm{H-2}$ specificity and maternal-fetal relationships may be due to antigens closely 
linked to the $H-2$ complex. The rôle of $H-2$ associated antigens is under investigation.

We are grateful to $\mathrm{Mr} \mathrm{J}$. Culverhouse for his technical assistance: D.P.H. was supported by a Medical Research Council studentship.

\section{REFERENGES}

Carter, J. \& Wrgmann, T. G. (1973) Mendelian segregation of a tolerance-inducing self-antigen in the spleen. Cell. Immunol. 7, 402-409.

Glarke, A. G. \& Hetherington, G. M. (1971) Effects of maternal pre-immunisation on the decidual cell reaction in mice. Nature, Lond. 230, 114-115.

Grafr, R. J. (1970) Polymorphism of histocompatibility genes in the mouse. Transplantation Proc. 2, 15-23.

Hetherington, C. M. (1971). The decidual cell reaction, placental weight, foetal weight and placental morphology in the mouse. F. Reprod. Fert. 25, 417-424.

Hetherington, C. M. (1973) The absence of any effect of maternal/fetal incompatibility at the H-2 and $\mathrm{H}-3$ loci on pregnancy in the mouse. F. Reprod. Fert. 33, 135-139.

Kirby, D. R. S., Billington, W. D. \& James, D. A. (1966) Transplantation of eggs to the kidney and uterus of immunised mice. Transplatation, 4, 713-718.

Searle, R. F., Johnson, M. H., Billington, W. D., Elson, J. \& Gatterbuck-Jackson, S. (1974) Investigation of $\mathrm{H}-2$ and $\mathrm{H}-3$ antigens on the mouse blastocyst. Transplantation, 18, 136-141.

Strong, L. G. (1942) The origin of some inbred mice. Cancer Res. 2, 531-539.

TAYLOR, B. A. (1972) Genetic relationships between inbred strains of mice 7. Hered. 63, 83-86. 